\title{
KOBZARDOM AS A PHENOMENON OF UKRAINIAN CULTURE IN THE CONTEXT OF THE NEW REALITIES OF DEMOCRATIZED SOCIETY
}

\section{Furdychko Andrii}

\section{INTRODUCTION}

In Ukrainian folk culture, many phenomena attract the attention of not only experts but also a certain circle of fans of folk art. Among them, the phenomenon of kobzardom is of particular significance. Its evolution, as well as other cultural phenomena, went through periods of formation, prosperity, decline, branching into two trends (reproductive and productive), revival in the days of Ukraine's independence. The discussions that are being held today between supporters of authentic kobzardom and representatives of the academic bandura performance concern the degree of approximation of each artistic direction to the true origins of this unique musical and social phenomenon of Ukrainian culture. But, at the heart of the contradictions, the main issue is the prospect of further development of this genre. Thus, despite the different views on kobzardom in different schools of performance, the only consensus on this issue is the unique phenomenon of the objects of a kind of dispute - „kobzas, lyres, banduras”, which encode the creative mental code of Ukrainians, ancient traditions and the history of the Kobzar movement itself. According to M. Budnik, one of the founders of the Kyiv Kobzar workshop: "... Only a song can bring us back in time, and a musical instrument can guide our journey and become a guide horse" ${ }^{1}$.

The study aims to analyze the development of kobza art in the historical and musicological aspects, to determine the impact of the Kobzar heritage of the Ukrainian people on the current state and the prospects of its further development, which is a novelty of the essence of

1 Yezhel Yu. (2017) Zrobysh banduru - vizmemo: Yak "posviachuiut" u suchasnykh kobzariv [You make the bandura - we will take you: how modern bandurists "are consecrated"]. Ukraina Moloda [Ukraine Young], 25 June, p. 13. 
the problem. The research methods are based on historicism, analysis, and synthesis of structural elements of this musicological phenomenon.

The historiography of kobzardom is extremely voluminous. Among collectors and propagandists of kobzars' creativity, we note M. Lysenko, P. Demutskyi, F. Kolessu, K. Kvitka, O. Slastion, O. Rozdolskyi, and others. Scientists have studied various aspects of the Kobzar movement. V. Lomykovskyi, M. Tserteliev, N. Maksymovych, I. Sreznievskyi, P. Lukashevich collected Ukrainian dumas and historical songs; P. Kulish, P. Yefimenko, Ts. Neiman, V. Borzhkovskyi, K. Studynskyi, M. Speranskyi, K. Kvitka studied the life, traditions, and customs of kobzars, bandurists, and lyrists; V. Peretz, P. Zhytetskyi studied the texts and poetics of dumas; F. Kolessa, N. Hrinchenko studied their musical form; M. Lysenko, H. Hotkevych, A. Humeniuk, S. Bashtan, L. Cherkaskyi investigated the history of musical instruments; F. Lavrov, B. Kyrdan, A. Omelchenko studied the biographies of famous kobzars. In modern times, S. Hritsa, M. Hrymych, V. Noll, O. Dubas, V. Dutchak, M. Pidhorbunskyi and others are actively engaged in the study of kobzardom. In particular, the vocal issues of genres of the repertoire of bandurists of the twentieth century are discussed by A. Omelchenko, V. Mishalov, N. Morozevich, L. Mandzyuk, I. Panasyuk and others in their writings. The problems of the revival of works of traditional kobzardom on diatonic instruments are covered in researches carried out by V. Kushpet and K. Cheremskyi. The position of the modern reproductive trend of kobzardom is represented in the works of V. Yesypka, B. Zheplynskyi, etc. But the issue of folklore in contemporary kobza art still needs more detailed study.

\section{Beginnings of the Study of Kobzardom}

Kobzardom became a symbol of Ukrainians in the world in the twentieth century. For many centuries, it was a familiar phenomenon for Ukrainian society. Interest in it appeared in the second half of the XIX century when in the light of the humanistic ideas of the "spring of peoples" and the strengthening of the process of creating national states in some European countries, they began to focus on the history and culture of their people. Naturally, kobzardom evoked considerable interest. At the end of the last century, blind people, elders, singers, beggars, who went from village to village or in crowded places (at markets or near churches) performed historical songs, dumas, and psalms. They sang and played humorous songs at weddings and in places 
of entertainment. Their main instruments were kobza, bandura, hurdygurdy, and torban. Most often, kobzars performed their repertoire with recitative.

The process of collecting information, studying and analyzing this work has led researchers to understand the archaic genesis of this phenomenon and the depth of the mentality of its carriers. Today's experts on this problem see the origins of the Kobzar and Duma art in the Gusli and Bylina tradition of Kyivan Rus. Other scientists link the kobzardom directly with the heroism of the Cossack era ${ }^{2}$. However, at the time of the birth of interest in kobzars, the activity of blind performers of folk songs (XIX - early XX century) was at the final stage. The mood of their songs became mostly sad. The Cossack epic disappeared from their repertoire: only some moralistic themes remained in the dumas, with the so-called lower songs, or ballads, mostly in historical songs; the haidamaks' songs, songs about the destruction of Sich, songs of the Chumaks almost became extinct ${ }^{3}$. It was already the "miserable" period of kobzardom. However, the spirit of the kobzars had not been broken yet. They managed to organize themselves into brotherhoods, create their internal statute, secret language, establish the admission of new members, their training, and were allowed to enter the profession only after serious examinations ${ }^{4}$.

Interest in specific personalities of performers of the Kobzar workshop arose and grew in the late XIX and early XX centuries. Thanks to this interest, information about such kobzars as A. Shut, O. Veresai, M. Kravchenko, H. Kozhushko, F. Kushneryk, Ye. Movchan, P. Nosach, O. Chupryna, P. Suprun, M. Budnyk, V. Horbatiuk, and others has been preserved to this day. The records contain texts and melos of Kobzar texts. The life and customs of the elders are also studied. In short, an attempt is being made to investigate the world of this particular

2 Khotkevych H. (2002) Muzychni instrumenty ukrainskoho narodu [Musical instruments of the Ukrainian people] (Reprint 1930). Kharkiv: DVU, p. 295.

${ }^{3}$ Cherkaskyi L. M. (2003) Ukrainski narodni muzychni instrumenty [Ukrainian folk musical instruments]. Kyiv: Tekhnika, p. 12.

${ }^{4}$ Trembitskyi A. M. (2008) Arho nosiiv ukrainskoho "nezriachoho" epichnoho mandrivnoho mystetstva: stan naukovoi rozrobky problemy [The Cant of the Bards of the Ukrainian "Blind" Wandering Epic Art: State of Scientific Development of the Problem]. Ivan Ohiienko i suchasna nauka ta osvita [Ivan Ohiienko and Modern Science and Education], vol. 5, pp. 110-148; Suprun-Iaremko N. O. (2010) Muzykoznavchi pratsi [Musicological works]. Rivne: O. Zen, pp. 54-61. 
community, which earned a living by musical creativity, while preserving the archetypal elements of folk culture. The need to preserve an authentic musical instrument was understood. Researchers such as M. Lysenko, P. Demutskyi, F. Kolessa, K. Kvitka, O. Slastion, and others were the most active in this field.

They perceived the bandura's design options somewhat differently. But there was no significant difference between them. F. Kolesov, for example, distinguished them by the number of strings and prystrunky (unstopped treble strings): Ostap Veresai's bandura - 6 strings and 6 prystrunky; Pavlo Bratuts' bandura - 4 strings and 16 prystrunky; St. Petersburg Conservatory's - 4 strings and 13 prystrunky; Mykhailo Kravchenko's - 5 strings and 18 prystrunky; Hnat Honcharenko's 5 strings and 15 prystrunky; Ivan Kucherenko's -5 strings and 16 prystrunky; Taras Parkhomenko's - 6 strings and 14 prystrunky ${ }^{5}$. These instruments are today referred to as traditional, folk or old-world banduras. The shape of the resonator and the manner of performance depended on the specific musician. The one standard version did not exist, much depended on the creativity of the Kobzar and the master who had made the tool. For a long time, kobza and bandura were considered identical instruments, and their names were synonymous.

Long before the middle of the last century, the instruments were designed by the folk masters or the singers themselves. In the post-war period, the mass factory production began, which was required by the new conditions for their use by large orchestras. This, of course, required the unification of their design and range, the way of playing, etc. Nowadays, thanks to the activities of modern music masters, the legendary kobza-bandura is being radically reconstructed. So, if in the past its body was round, convex, and pear-shaped, today it has a convex shape with an asymmetrically set neck (as a result of increasing the strings); the number of basses and strings has been increased, and the sound range has been chromatized.

Some researchers of kobzars' creativity see a common worldview platform in topics devoted to the tragic pages of the history of the Ukrainian people, the struggle against oppressors, social justice, national liberation, everyday life, family relations, and morality. O. Bohdanova, for example, believes that her main moral and aesthetic principles were

${ }^{5}$ Kolessa F. (1969) Melodii ukrainskykh narodnykh dum [Melodies of Ukrainian Folk Dumas]. Kyiv: Naukova dumka, pp. 51-52. 
the comprehensive dissemination of ideas of religious preaching, a kind of "people's Christianity", which was closer and more understandable to ordinary people than the Church ${ }^{6}$. And this consideration, in our opinion, has a right to exist.

\section{Kobzardom in the Conditions of Soviet Power}

The social cataclysms which were brought by the First world war (1914-1918) and the civil war that completely enveloped Ukraine, and then the coming to power of the Bolsheviks radically changed the political landscape in the former Russian Empire, which became the Soviet Union. At the same time, a new state ideology emerged, which critically and sometimes mercilessly treated both religion and various prejudices. This category also included folk musicians-beggars who sang mournfully about the past and were not at all happy for the "bright future" that awaited the working people. Authentic kobzars, elders, blind singers got into trouble with the new government. And the new officials did not avoid bandit methods of dealing with ideological opponents. Kobzars I. Lytvynenko, A. Slidiuk, and F. Dibrova were killed by Bolsheviks in Ekaterinodar in 1919; and A. Mytiai, S. Sotnychenko, and P. Skydan - in 1920. The researcher of kobza art B. Zheplinskyi set up the register of kobzars and lyrists killed by the Bolsheviks or missing. There were 72 people in it ${ }^{7}$. In the mid-1920s, regulations were issued to struggle against traditional music ${ }^{8}$. Many kobzars died during the collectivization and Holodomor in 1932-1933, while others were subjected to repression and destruction ${ }^{9}$. There was a problem of fading of this genre of folk art, as unnecessary in the new historical realities.

${ }^{6}$ Bogdanova O.V. (2002) Lirnytska tradytsiia v konteksti ukrainskoi dukhovnoi kultury [Lyric tradition in the context of Ukrainian spiritual culture] (PhD Thesis). Kyiv: Ukrainian National Tchaikovsky Academy of Music, p. 3.

${ }^{7}$ Bozhko M. O., Pasko M. V. (2015) Dukhovni nastavnyky narodu: kobzarstvo $v$ Ukraini: Bibliografichnyi narys [Spiritual Mentors of the People: Kobzardom in Ukraine: A Bibliographical Essay]. Kyiv: Centralized library system of the Shevchenkivskyi district of Kyiv, pp. 41-43.

${ }^{8}$ Chaika S. V., Chaika M. M. (2012) Kobzarstvo - diievyi chynnyk zberezhennia tradytsii dukhovnoho zhyttia natsii [Kobzardom is an effective factor in preserving the traditions of the spiritual life of the nation]. Pedahohichna osvita: teoriia $i$ praktyka [Teacher education: theory and practice], vol. 12, pp. 439-446, p. 442.

${ }^{9}$ Cheremskyi K. (1999) Povernennia tradytsii. Z istorii nyshchennia kobzarstva [Return of traditions. From the History of the Destruction of Kobzardom]. Kharkiv: Les Kurbas Centre. 
Famous musicologist M. Khai felt this tendency in the development of instrumentation: "With the extinction of production-labor, ritual-rite, calendar and family-everyday traditions in most regions of Ukraine, the corresponding functions of folk instruments died out" ${ }^{\prime 10}$.

The new government failed to overcome such a phenomenon as kobzardom, etched into the national memory, immortalized by the creativity of T. H. Shevchenko. The course was chosen to create an academic bandura performance that would avoid religious motives. Two directions of the Bandurist's performing arts were gradually crystallizing, which were not separated by the way of playing, but by the forms of the functioning of the instrument, i.e. folk and concertacademic. The last one was closely related to the names of H. Khotkevych, L. Haidamaka, V. Yemets, and M. Teliha. ${ }^{11}$ Even contemporary Bandura art continues to evolve in two directions: kobzardom with the preservation of the traditional repertoire and the accompanying function of the instrument, with an effort to revive the authenticity of the instrumentation and performance (reproductive function) and academic bandura performance (bandurism), which is divided into solo instrumental, vocal-instrumental, and ensemble with an upgrade of the instrument design, its performance, and repertoire (productive function) $^{12}$. At that stage kobzardom as a social phenomenon almost disappeared and a new genre (academic bandurism) developed as an aesthetic phenomenon. The first concert performance of professional bandura performers (Bandurist Quartet) in Kharkiv in 1928 played a significant role in the formation of Bandura academic performance practice $^{13}$.

10 Khai M. (2007) Muzychno-instrumentalna kultura ukraintsiv (folklorna tradytsiia) [Musical-Instrumental Culture of Ukrainians (Folk Tradition)]. Kyiv; Drogobych: Kolo, p. 177.

11 Dutcheak V. G. (2010) Myhailo Teliga: postati myttsya v kontexti epohy [Mykhailo Teliga: The Figure of the Artist in the Context of the Era]. Naukovyi vistnyk Natsionalinoi Muzychnoyi Akademiyi Ukrainy of P. Cyaikovski, vyp. 91, p. 249.

12 Panasiuk I. V. (2008) Tvorcha diyalinisti S. V. Bashtana v kontecsti stanovlenya Kyivskoi shkoly akademichnogo bandurnogo vykonavstva [The Creative Activity S.V. Bashtan in the Context of the Establishment of the Kyiv School of Academic Bandura Performance] (PhD Thesis). Kyiv: Ukrainian National Tchaikovsky Academy of Music, p. 4.

${ }^{13}$ Vavryk O. (2006) Kobzarski shkoly v Ukraini [Kobzar Schools in Ukraine]. Ternopil: Zbruch, p. 133. 
Representatives of the new, "proletarian culture" were sometimes critical of Kobzardom as an art. There were opinions about the irrelevance and inappropriateness of the old bandurism to the new tastes. They expressed their reluctance "to return to antiquity in the age of electricity...". The other believed that the instrument died along with its era, its repertoire is outdated, and the bandura itself is "too quiet, too sad, not native to the proletariat, because it was not born in the smoke of factories or under the roar of tractors, and because of this kobza is not mass and not popular"14.

\section{The Productive Period in Bandurism}

Contrary to this understanding of the problem, the prevailing opinion of the power circles was that it was necessary to support this folk tradition and use it for the benefit of the new ideology. The productive function of bandurism began to improve. The growing interest in the art of kobzars should be acknowledged. This contributed to the appearance of kobzar instruments on the stage. Here it is more often called the bandura, not the kobza, and performers - both kobzars and bandurists.

One of the researchers of the evolution of Ukrainian folk instruments L. Cherkaskyi noted several directions of entry of the kobza-bandura in the sphere of concert activity in his monograph: 1) improvement of the instrumentation by extension of a sound line, introduction of chromatization, improvement of technical possibilities of performance, modernization of the design of instrument material, modernization of its production; 2) improvement of the level of performing skills through the study of music theory, mastery of high vocal technique and instrumental performance, as well as artistry; 3) the origin and development of ensemble forms of performance (the formation of kobza duets, trios, ensembles, and chapels); 4) expansion of the repertoire of concerts, including classical instrumental and vocal-choral works. All these directions, in his opinion, were and remain interconnected and dependent on each other ${ }^{15}$.

New performing practices (ensemble and chapel) required the unification of the instrument. Initially, this process involved expanding

14 Sliusarenko T. O. (2016) Bandurne vykonavstvo yak yavyshche natsionalnoi kultury [Bandura Performance as a Phenomenon of National Culture] (PhD Thesis). Kharkiv: I. P. Kotlyarevsky Kharkiv National University of Arts, p. 147.

${ }^{15}$ Cherkaskyi L. M. (2003) Ukrainski narodni muzychni instrumenty [Ukrainian folk musical instruments]. Kyiv: Tekhnika, p. 11. 
its range of sounding. The most common were the two types of bandura and the associated two ways of performing - "Kharkiv" and "Kyiv", then all design searches were carried out in two directions, with mutual influences and borrowings. String diameters, their number, location, and anchoring were improved. Equal temperament made it easier to tune the bandura, but it remained a diatonic instrument ${ }^{16}$. H. Khotkevich became a beginner in improving the bandura; O. Korniievskyi gradually achieved chromatization of the bandura's scale; K. Nimchenko, I. Skliar, and V. Tuzychenko created the improved bandura of the Kyiv model; V. Herasymenko created more than 40 models of bandura of the Lviv and Kharkiv models. Wonderful instruments were produced by the masters of the Chernihiv and Lviv musical instrument factories. V. Kabachok, S. Snihiriova, S. Bashtan, A. Sheptytska, L. Fedorova, L. Dediukh, R. Hrynkiv, and others made their efforts to improve the bandura ${ }^{17}$.

The process of development of academic bandurism on a large scale needed the system of professional education. In this area, it is impossible not to mention the efforts to teach the bandura class at UNTAM Tschaikovsky. The bandura class was founded here in 1950. M. Polotai, V. Kabachok, A. Bobyr, M. Helis taught here the art of bandura. S. V. Bashtan devoted many years to this work. The professor and his students created a productive school for academic bandura performance. Written by S.V. Bashtan, co-authored with A. Omelchenko, the book Bandura School (1984) was the first educational and methodological basis in Ukraine for the education of high-level performers. He carried out fundamental work on the selection, systematization, editing of the repertoire for bandurists of all levels and contributed to their publication in the publishing house "Music Ukraine" (33 issues of "Bandurist's Library", 30 issues of "I would take the bandura", 12 issues of "Bandurist's Repertoire", etc.). In 2011, the Bandura Department was

${ }^{16}$ Panasiuk I. V. (2013) Kafedra bandury NMAU imeni P. I. Chaikovskoho ta peredumovy yii stvorennia [The Department of Bandura UNTAM Tschaikovsky and Prerequisites for its Creation]. Naukovyi visnyk Natsionalnoi muzychnoi akademii Ukrainy imeni P. I. Chaikovskoho [Scientific herald of Tchaikovsky National music academy of Ukraine], no. 107, p. 258.

17 Hrynkiv R. D. (2010) Shliakhy udoskonalennia konstruktsii zvukoriadu bandury [Ways to improve the bandura scale design]. Chasopys Natsionalnoi muzychnoi akademii Ukrainy imeni P. I. Chaikovskoho [Journal of Tchaikovsky national music academy of Ukraine], no. 1(6), pp. 61-67. 
created at the Orchestra Faculty of UNTAM Tschaikovsky comprised of 16 teachers in the specialty, vocal, ensemble and conducting ${ }^{18}$.

Similar traditions of bandura art continue at Kharkiv National University of Arts named after I. P. Kotlyarevsky. For the first time in Kharkiv in 1926, S. P. Drimtsov initiated the foundation of the bandura class at the Music and Drama Institute (since 1934 - Conservatory), which was headed by H. Khotkevych. A professional school of kobza art was founded at this institution, which V. Kabachok, L. Finkelberg, L. Levando, and others graduated from. After H. Khotkevych's death in 1938, the bandura class disappeared and was fully renewed in 1989 by L. Mandziuk at the Department of Folk Instruments. Today at the University there is a bandurist chapel directed by N. Melnyk.

In 1954 a bandura class was opened at the Department of Folk Instruments of Lviv National Musical Academy named after Mykola Lysenko. It was headed by V. Herasymenko, who trained more than 100 professional bandurists during his teaching career. Even today, the department employs professors well-known in Ukraine and far beyond its borders: O. Herasymenko (directs the bandurist quartet), People's Artist of Ukraine, prof. L. Posikra. Since 1962, the Academy has had an ensemble of bandurists ${ }^{19}$. A significant contribution to the development of Kobzar art of the region and its research was made by B. Zheplynskyi, who in the 1950s was exiled to hard labor in Siberia, where he and his brother Roman created a chapel of bandura-convicts. After returning from exile in the time of independence, he headed the Lviv branch of the all-Ukrainian (now - National) Union of kobzars of Ukraine.

Famous artists and scientists such as V. Yesypok, people's artist, professor, N. Broiako, honored artist of Ukraine, professor, P. Chukhrai, T. Yanytskyi, A. Ivanysh (artistic Director of the Bandurist chapel), bandurist virtuoso, people's artist of Ukraine, professor, head of the department of bandura and kobzar art, M. Pidgorbunskyi teach at the

${ }^{18}$ Panasiuk I. V. (2013) Kafedra bandury NMAU imeni P. I. Chaikovskoho ta peredumovy yii stvorennia [The Department of Bandura UNTAM Tschaikovsky and Prerequisites for its Creation]. Naukovyi visnyk Natsionalnoi muzychnoi akademii Ukrainy imeni P. I. Chaikovskoho [Scientific herald of Tchaikovsky National music academy of Ukraine], no. 107, pp. 259-260.

19 Davydov M. A. (2010) Istoriia vykonavstva na narodnykh instrumentakh (Ukrainska akademichna shkola) [History of Performance on Folk Instrument (Ukrainian Academic School)]. Lutsk: Volynska oblasna drukarnia, pp. 114-117, 134-137. 
bandura and kobzar performance department of the Kyiv University of Culture and Art.

The Bandurist Quartet "Herdan" (lead by Professor V. Dutchak) was nominated at the 3rd All-Ukrainian Open Festival-Competition of Performers on Folk Instruments "Merezhyvo" ("Lace") (April 23-26, 2017) they took the first place and got the title of laureates. This showed an excellent level of teaching the course for bandurists of the academic genre at the Department of Folk Instruments at Vasyl Stefanyk Precarpathian National University.

Professor N. Morozevych initiated a special bandura class at the Department of Folk Instruments at The Odessa National A. V. Nezhdanova Academy of Music. Simultaneously N. Morozevych leads the trio of bandurists "Malvy" ("Mallows") at Odessa's Philharmonic Theatre.

A professional bandura school has also appeared in Dnipropetrovsk region. Lidiia Vorinova played a great role in it. She created the ensemble "Charivnytsi" ("Sorceresses"), achieved the opening of the bandura class at Dnipro Conservatory, together with her students held nine concerts of the festival "Dzveni, bandura!" ("Ring, bandura!") ${ }^{20}$.

I. Kuchuhura-Kuchurenko, V. Yemets, V. Kabachok, H. Khotkevich (the first half of XX century), S. Bashtan, V. Herasymenko, N. Broiako, O. Varvyk, O. Herasymenko, V. Dutchak, L. Mandziuk, N. Morozevych, L. Posikra, R. Voit, R. Hryniv, N. Melnyk, K. Novytskyi, L. Fedorova (the end of XX-beginning of XXI century.) and others became wellknown far beyond the borders of Ukraine for their academic performance on the bandura. This brought worldwide fame to Ukrainian musicians, which contributed to the spread of our folk culture abroad.

Among the active groups of our country of the modern period, the following should be mentioned: the Bandurist chapel "Carpaty" ("Carpathians") of the Ukrainian society of the blind, in which $70 \%$ of bandurists are visually impaired; folk Bandurist chapel "Chervona Kalyna" ("Guelder rose") "Vyshyvanochka" ("Embroidery"), "Zorinytsia" ("Daw"), "Dzvinochok" ("Bell") and "Halychanka" (Lviv); Bandurist chapel "Zacharovana Desna" ("Enchanted Desna") of Lev Revutskyi Chernihiv music school; Ivano-Frankivsk Bandurist Chapel;

${ }^{20}$ Cherneta T. O. (2009) Vydatni muzykanty Dnipropetrovshchyny. Lidiia Vorina [Outstanding Musicians of Dnipropetrovsk Region. Lidiia Vorina]. Dnipropetrovsk: Yurii Serdiuk. 
Bandurist trio "Verbena" (Cherkasy), Bandurist Quartet "Lvivianka" (Lviv), duet "Bandurna rozmova" ("The talk of banduras") (Lviv), Bandurist trio "Malvy" ("Mallows") (Odessa), Bandurist sextet "Charivnytsi" ("Sorceresses") (Dnipro), trio "Oriana" (Ternopil), national honored Bandurist Chapel of Ukraine named after H. I. Maiborody, Strusiv honored Bandurist chapel of Ukraine "Kobzar", Bandurist chapel named after T. H. Shevchenko from the USA, Canadian Bandurist chapel, Cherkasy municipal Bandurist chapel, Municipal Bandurist chapel of Ivano-Frankivsk, children's ensembles "Yahilka", "Hamaliia "(Lviv) "Little falcons" (Chernihiv), etc.).

\section{The Reproductive Course of Kobzardom}

After the Second world war (1939-1945), the old "conservative" people's household branch of Kobzardom gradually began to revive. H. Tkachenko put a lot of effort into this process. He worked at fundamental research of kobzardom, laid the foundations for the revival of the traditional bandura performance, the skills of which he adopted from P. Drevchenko and passed on to his students: M. Budnyk, M. Tovkail, V. Mishalov, and other famous kobzars.

With the beginning of the democratization of Soviet society, the attention to the ancient folk traditions increased. Kobzar art aroused the interest of the younger generation. The interest turned into a whole movement. L. Ivannikova described the emotional state of supporters of this movement in the late 1980s: "... Everyone was anxious about the revival of the idea of kobzardom. It was not only about singing and playing, not only performing in concert halls, but also on the streets, in parks, even in markets, and at the same time about making (and later reconstructing) ancient traditional instruments such as the bandura, kobza, lyre, and even gusli. All this required turning to scientific literature and archival sources, to expedition work, i.e., a serious study of a unique phenomenon in the world culture. So out of the romanticallyoriented amateurs, the following extraordinary figures in Ukrainian science appeared: V. Kushpet (bandurist, torbanist, kobzist, master of instruments), author of the monograph "Eldership. Wandering Musicians in Ukraine (19th - early 20th centuries)" (Kyiv, 2007), K. Cheremsky, who studied the archives of the Department of Home Affairs-NKVD and wrote several monographs on the history of the destruction of kobzardom in the XXth century and its revival in the post-Soviet times ("Return of Traditions. From the History of the Destruction of Kobzardom" 
(Kharkiv, 1999), "The Way of Customs" (Kharkiv, 2002)) and others. This cohort also includes M. Khai, a Ukrainian instrumental musician well-known in Ukraine and abroad, author of numerous articles and monographs on this subject, Doctor of Arts and a practicing lyricist ${ }^{21}$, also known as lyricist Stefan.

The result of this movement was the creation of the all-Ukrainian Kobzar Union (1990). Kobzars' congresses, festivals of Kobzar art, competitions, concerts, and anniversary evenings were held thanks to the activities of V. Lytvyn, V. Horbatiuk, and V. Yesypok. M. Budnyk organized the Kyiv-Irpinsk Kobzar workshop, around which the conscious Ukrainian youth gathered, passionate about the idea of reviving the national culture: students, scientists, musicians, and music masters. On the ancient principles of the Kobzar brotherhood, young boys -made authentic samples of kobzas, banduras, hurdy-gurdies, torbans, gusli, hudoks, and violins. At the same time, they learn to play these instruments and organize exhibitions of their products. For many of them, kobzardom became a professional activity. From the group performances that had been practiced earlier, they moved to kobza performances in crowded places: on streets, squares, underpasses, near churches, and cathedrals. According to the Kobzar tradition, they pray and confess in the Church of the Intercession, consecrate their instruments, celebrate religious holidays, and adhere to the Orthodox fast $^{22}$.

Based on the ancient traditions of the Kobzar brotherhood, there are three workshops in Ukraine today: Kyiv kobzars (M. Tovkailo), Lviv lyrnists (M. Khay), and Kharkiv kobzars (K. Cheremskyi). Their main activity is focused on recreating the Kobzar tradition of making musical instruments, as well as performing authentic Kobzar repertoire on them ${ }^{23}$.

${ }^{21}$ Ivannikova L. (2016) Khai M. Mykola Budnyk i kobzarstvo [Khai M. Mykola Budnyk and kobzardom] (Review) . Studii mystetstvoznavchi [Art History Studios], no. 1, pp. 110-111.

22 Cherkaskyi L. M. (2003) Ukrainski narodni muzychni instrumenty [Ukrainian folk musical instruments]. Kyiv: Tekhnika, p. 163.

23 Chaika S. V., Chaika M. M. (2012) Kobzarstvo - diievyi chynnyk zberezhennia tradytsii dukhovnoho zhyttia natsii [Kobzardom is an effective factor in preserving the traditions of the spiritual life of the nation]. Pedahohichna osvita: teoriia i praktyka [Teacher education: theory and practice], vol. 12, p. 444. 
Today there are workshops for the production of traditional musical instruments in Kyiv, Lviv, Kharkiv and Poltava region. With the support of local creative associations, they carry out their activities privately and serve as true centers of the revival of the folk music tradition. The workshops train specialists in the production of instruments and performers. Kobzar camp, founded by Yu. Fedynskyi in a family house in the village of Kriachkivka is indicative in this respect. They organize tutorials on making musical instruments during cultural events, festivals (in particular, "Kobzar Triitsa" ("Kobzar Trinity"), "Kobzar-lyric Pokrova", "Kraiina Mrii" ("Dreamland"), "Mazepa-fest", etc.), concerts, etc. The project of the Mobile Kobzar Workshop, which is carried out by the Kharkiv Kobza Workshop in educational institutions of the region and involves direct participation in mastering the tools of a wide range of pupils, students, and youth communities, is quite promising. Since 2008, the Kyiv workshop has been holding the "Kobzar Triitsia" ("Kobzar Trinity") festival, which includes tutorials in making and playing musical instruments.

According to K. Cheremskyi, analyzing the causes of this movement as a phenomenon of spiritual life, participation in the activity of the kobzar workshop is an internal spiritual call, which "can hardly be understood from rational positions, because authentic kobzardom is a peculiar state of mind, a response to the need for a constant sense of depths of eternity, the voice of the ancestors, proven over centuries source of strength, spiritual and creative inspiration, effective psychoregulation and healing, our reliable protection for the future" ${ }^{24}$.

There are examples of the emergence of new centers whose activities fall under the name of new Kobzar schools. It refers to Stritivka Higher Pedagogical School of Kobza Art. It was created in 1989 on the initiative of V. Lytvyn, B. Oliinyk, and O. Berdnyk. Since 2014, it became "Stritivka Pedagogical College of Kobza Art". At the moment, the College reports on the training of more than 250 bandurists-singers.

Representatives of the reproductive movement from the end of the 1980s began to practice singing and playing the Kobzar-lyric authentic music on the streets and at the holy places (M. Budnyk, V. Kushpet, M. Khai, etc.). The copying of the "aging" timbre and the "infirm" intonation became the sign of this movement. Another sign of the revival

${ }^{24}$ Cherkaskyi L. M. (2003) Ukrainski narodni muzychni instrumenty [Ukrainian folk musical instruments]. Kyiv: Tekhnika, p. 4. 
of authenticity is the repertoire. It includes restoring old transcriptions, archival material, real kobzar dumas, historical songs that were performed by blind singers of the second half of the XIX - early XX century. This repertoire includes real pearls of Kobzar art: dumas "Crying of the Slave," "About Samiilo Kishka" (written by lyrist I. Scubii in the village of Leliukhivka, Poltava region, O. Slastion, trans. by F. Kolessa), variant of duma "About Marusia-Bohuslavka" (taken over using auditory method by M. Budnyk from H. Tkachenko), dumas "About the Escape of Three Brothers from the City of Azov" (reconstructed by the auditory method (by H. Tkachenko)) [Kolesya registered it under the name "About Azov brothers"], "About Khvedor the Unfortunate-Rootless. Historical songs in their performance include such works as "Maksym, Cossack, Zalizniak", psalms "There is no Truth in the World" (taken in a "live way", orally from H. Tkachenko in the 1960s), "About Lebedenko" (recorded by P. Barylchenko in the village of Nyzhnia Pysarivka (Kharkiv region) D. Yavornytskyi), cants "Oi, across the Bridge, Bridge" (recorded by M. Khai from P. Zhadan in the village of Chernechchyna (Kharkiv region)), "Archangel Michael" (reconstructed from the hand-written collections of the National Museum in Lviv (M. Vozniak's archive)) and "About Pochaiiv God Mother", the satirical song "The Wedding of the Hare" (taken orally from the last blind lyrist I. Smyk (I. Vlasiuk, Zaliuttia (Volyn)).

In their performances, the masters of this movement use authentic musical instruments: the hurdy-gurdy (M. Khai, V. Shevchuk, Yu. Kondratenko, etc.), the old-world bandura (M. Tovkailo, V. Kyrylych, N. Cherkas, etc.), the so-called "kobza of O. Veresai" (T. Kompanichenko, A. Seletskyi, Yu. Fedynskyi, etc.).

In 1999, the All-Ukrainian Union of Kobzars was reorganized from the public organization of kobzars (1995 creation) and got the status of the National public organization. It concentrated in its ranks all the manifestations of kobzardom of Ukraine. Thanks to the work of the Union, 10 regional and 3 city branches of the National Union of Kobzars of Ukraine (NUKU) were organized. In general, the organization has 450 bandurists and kobzars of different age categories. The head of the NUKU is V. M. Yesypok - people's artist of Ukraine, Professor. One of the main tasks of the Union is to establish a systematic nature of collecting and recording Kobzar heritage, audio and video recordings of the performing style of kobzars who are more than 60 years old. The Union released 5 collections of the Bandurist's repertoire "Hey, hit the strings, kobzari" (compiled by V. Yesypok), "Etudes for bandura" 
(compiled by L. Mandziuk), "Our Duma" (compiled by Halii-Muravska), and others.

The same artistic Union initiated and held the international festival, I and II competitions of Kobzar art named after H. Kytastyi. NUKU promotes and participates in the traditional festivals of Kobzar art "To the silver sound of banduras" in the city of Mykolaiv, the festival of kobza art named after K. Misevych in Rivne region, Yu. Synhalevych in Lviv region, V. Perepeliuk in Vinnytsia region, "Bandura is ringing in the city of Frankiv" - in Ivano-Frankivsk, the International festival of Bandurist ensembles in Dnipropetrovsk, the festival of Kobzar art "Ring, bandura, in Cossacks' land", Dnipro. To date, five congresses of kobzars of Ukraine have been held (the last one was in December 2014). We also note the organization of ethnic festivals "Kobzar-lyric Intercession": "Lyric Intercession in Drohobych" (2012), " Kobzar-lyric Intercession in Kyiv" (2013, 2014, 2015, 2016), "Lyric Intercession in Rivne" (2014, 2015, 2016). To attract young people to the ancient music art, the All-Ukrainian competitions were launched: the Competition for Young Bandurists named after V. Kabachok in Poltava region, All-Ukrainian Competition for Young Bandurists "Volyn Kobzaryk", Cherkasy Children's Competition for Young Bandurists "Kobzarevi Dzherela" ("Kobzar sources") and more.

The philosophy of the kobzar tradition includes not only singing and music but also conversation with the listener, moralizing on the theme of historical truth, nature of behavior, respect for others, love of God, etc., where they sound and are interwoven in the comparative aspect of the problems of the past and present (national concept "historical memory" Cossack victory, Sich archery, UPA heroism, famine, political exposure, ridicule of the tsar, the Soviet Union and present aggression of Russia, etc.).

Many artists have been brought up in a fairly widespread movement to revive Kobza art, and they have practically linked their professional fate to the reproductive stream. But even among them, some bands and performers have earned the love and popularity of the general public with their talent. Nowadays, Vasyl Zhdankin is considered to be the cult singer, bard, kobzar, performer of folklore texts, singing poetry and author song. Albums - "Thresholds are beating" (1991, republished in 2006), "Confession" (2006). The artist's repertoire of folk music consists of Cossack, Patriotic texts of an epic nature and songs on religious themes, which are performed to the accompaniment of a six-string kobza ("Oi, the evening dawn has risen", "Song of Polish immigrants", "What happened to us from the beginning of the world", "Oi, the Eagle Owl sat 
on the Tomb", "the Legend of Noah", etc.). The singer has a special, magnificent bass timbre, and he strongly professes Eastern Orthodox rite. $\mathrm{He}$ is considered to be one of the last kobzars of our time.

Accompanied by the veresaivska kobza, the old-world bandura, and hurdy-gurdy, Eduard Drach performs as a performer and reconstructor of the traditional Kobzar-lyric repertoire, which belongs to the community of the "Kyiv Kobzar workshop". In addition to the author's texts, he sings and plays folk material, i.e. "Zaporizhzhia songs", Cossack psalms, chivalric songs, slave lamentation, prayerful songs, devout psalms and cants, spiritual and secular lyrics. Another outstanding personality is Volodymyr Yesypok. He is a Ukrainian bandura singer (bass), People's Artist of Ukraine (2007), Professor, Head of the National Kobzars Union of Ukraine. His repertoire: duma "About the Cossack Bandurist", "About Cossack Holota", historical "From Poltava battle", "Maksym Cossack Zalizniak", chumatski, family and household, lyrical, comic songs. Sashko Lirnyk (Oleksandr Vlasiuk) became widely known as a storyteller and lyrist who plays such folk musical instruments as the hurdy-gurdy, kobza, and bandura. In 2003, the disk "Tales of lyrist Sashko for adults and children" was considered to be the best album in Ukraine (the results of a survey by the magazine "Politics and culture"). Performer Viktor Pashnyk (pseudo - Shkrum, 1980; studied at Stritivka Kobzar School) seeks to fully stylize his life under the kobzar's wandering philosophy, so he travels the world and sings to the kobza in the open air. His album "Kobzar Shkrum" (2009) was recorded accompanied by a bandura. There are the following Ukrainian folk songs in the repertoire: "How I went home from Debrechyn", "Gray pussycat", "The girl went through the meadows", "My mother beat me".

One of the famous students of professor V. Herasymenko is a bandurist Taras Lazurkevych. Joint work with his teacher allowed him to take part in the decoding of phonorecords of old dumas, psalms, historical songs, and instrumental music. He launched an active work in the reconstruction of ancient song texts of kobza art. His repertoire includes Ukrainian folk historical dumas "About Cossack Holota", "About the Three Brothers from Azov" and "About Marusia Bohuslavka". Together with another student of V. Herasymenko, Oleh Sozanskyi, he founded the duet "Bandurna rozmova" ("The talk of banduras"). Also, the performer, together with his teacher and other bandurists created the international fund "Kobzar". The main objectives of the organization are comprehensive assistance and contribution to the development of Kobzar art. 
The band "Chorea Kozatska" (2005) is particularly noteworthy. It is a Kyiv music group that performs an ancient Ukrainian melos of different eras: the Middle Ages, Renaissance, Baroque, Classicism, Romanticism and individual works of the XX century. The band performs songs that have been found in archives, manuscripts, and printed collections. The repertoire covers the following genres: dumas, historical, heroic and rebel songs, hymns, psalms, cants, and spiritual concerts. Albums of the group: "Carmina Sarmatica" (2009), "Knight Thrilled with Courage (Concert in Lutsk castle)“" (2009), collaboration with "Guliaigorod" "Terra cosaccorum" (2010) and "Spiritual Feast" (2013). The team consists of several professional bandurists and lyrists. The leader of the group T. Kompanichenko plays the "bandura of Ostap Veresai" (according to the description of M. Lysenko), lyra, old-world bandura.

In addition to solo practice and work in "Chorea Kozatska", T. Kompanichenko sings in the international choir "Academy of traditions". The institution consists of singers and musicians from the countries of Central and Eastern Europe. Meetings take place not only in the form of concerts but also seminars on ancient European music are held. In addition to singing in Latin, German, French, Estonian, Lithuanian, Belarussian, Russian, works in Church Slavonic (with Kyiv phonetics) and ancient Ukrainian-Russian languages are performed and restored. Also, T. Kompanichenko is a member of the group "The Carpathians" (2003) (the leader of the group - Yu. Fedynskyi is an American of Ukrainian descent, artist-polyinstrumentalist). Most of the members of the band were previously engaged in authentic music, which strengthens the main credo of the group - to make ethnocultural creativity. The band performs mostly forgotten or completely unknown to the public Ukrainian folk songs collected during folklore expeditions throughout Ukraine (Carpathian kolomyiky, Polesia vesnianky, wedding marches of the Steppe region in combination with elements of rock, jazz, avant-garde, and so on). During the group's performances, the combination of traditional instruments on one stage, such as the bandura, tsymbaly, kobza, pipes, and hurdy-gurdy, is characteristic.

Band "Shpyliasti Kobzari" resorts to a creative combination of Ukrainian folk melodies to the accompaniment of the bandura with contemporary music styles. This is a group of six young bandurists who perform original songs, instrumental works, cover versions of world hits and Ukrainian folk songs in a modern format in the style of "musical cartoon" ("Banduryste, Orle Syvyi!" ("Bandurist, Eagle Dove!"), "Marusia", "Shchedryk", " Oi, sluzhyv ya u pana..." ("Oh, I served at the 
lord's ...") and the like). The initiator of the band is a young bandurist Ya. Dzhus, who also created a project for the development of the bandura brand "Bandura style", which is aimed at popularizing the Ukrainian musical instrument and Ukrainian musical culture as part of the modern art space. The achievements of the project include the organization of the Scene of modern bandura at the Ethno festival "Kraina Mrii" ("Dreamland"), the release of the music collection "12 instrumental works for bandura", etc.

\section{CONCLUSIONS}

Kobzardom as a cultural phenomenon, along with a set of folk musical instruments inherent in the creativity of kobzars, bandurists, lyrists, is the property of Ukrainian art, which has contributed to the education of the masses for centuries. It attracted the attention of scientists in the second half of the XIX - early XX century, which allowed, although at the final stage of authentic development, to study it in various research perspectives. For objective historical, socio-cultural and political reasons, in the first half of the twentieth century, traditional kobzardom was destroyed, but the academic bandura performance supported by the state received an extraordinary development. It significantly deviated from the authentic sources of kobzardom, despite this, it was popular with its people and brought them world recognition, allowed them to prepare a whole cohort of bandurists-virtuosos and experts, expand their repertoire, improve folk musical instruments, and diversify their concert activities. The revival of authentic kobzar art today is a symbol of the Renaissance of the Ukrainian national spirit. And this is seen as a positive factor in its reproductive potential. Undoubtedly, the actual folklore heritage in this course is more than in academic performance, which is the answer to the question posed in the aim of this study. But at the same time, we would like to emphasize that both directions of kobzar culture are the property of modern Ukrainian culture, and the help from the state can become a key factor for overcoming differences between them, which would play an important role in patriotic education of young people.

\section{SUMMARY}

In the second half of the nineteenth century, interest in traditional musical culture increased significantly and the researchers drew attention to such a folklore phenomenon as a kobzardom, which later became the symbol of Ukrainianity in the world. 
The article examines the development of kobzar art in the historical musicological aspect, determines the influence of the kobzar heritage of the Ukrainian people on the present state and prospects for its further development. The phenomenon of kobzar art (along with accompanying national musical instruments), as the property of Ukrainian culture, is determined. The revival of authentic kobzar art today is a symbol of the era of the renovation of the Ukrainian national spirit. And this is seen as a positive factor in reproductive direction.

Today there are some contradictions between the supporters of the authentic kobzas and the representatives of academic bandura performance. They are based on the degree of proximity of each artistic direction to the true sources of this unique musical and social phenomenon of Ukrainian culture. The problem becomes acute on the background of the prospects for further development of this genre. However, the contradictions between professional and amateur performing schools have only one consensus on this issue - this phenomenon and the objects of a particular dispute ("kobza, lyre, bandura") encode the creative mental code of Ukrainians, old traditions and the history of the kobza process.

From objective historical, socio-cultural and political reasons in the first half of the twentieth century the traditional kobzar art was destroyed, and the state-sponsored academic banda's execution got considerably developed. In spite of this, it departed significantly from authentic sources of kobzars, enjoyed popularity among people and brought it worldwide recognition, made it possible to prepare a whole cohort of virtuoso bandurists, specialists in their work, to expand the repertoire, to improve folk musical instruments, to diversify concert activities.

The aim of work is to give analysis for the influence of folk music on the modern Ukrainian Cossack art and prospects of its development, this represents a novelty in terms of the problem. Methods: historical musicological analysis and synthesis.

Kobzardom phenomenon in Ukraine is unique, it has existed for centuries. For some objective reasons at a certain historical period academic bandura performance was dominated, this departed from authentic sources of kobzardom tradition. At the time of the independence the revival of authentic (reproductive) kobzardom flow began, which is, in our opinion, a positive phenomenon. 
Today, both currents of art are the property of the Ukrainian culture, which requires an effective state aid in the form of extraordinary importance in the patriotic education of youth.

\section{REFERENCES}

1. Bogdanova O. V. (2002) Lirnytska tradytsiia $v$ konteksti ukrainskoi dukhovnoi kultury [Lyric tradition in the context of Ukrainian spiritual culture] (PhD Thesis). Kyiv: Ukrainian National Tchaikovsky Academy of Music.

2. Bozhko M. O., Pasko M. V. (2015) Dukhovni nastavnyky narodu: kobzarstvo v Ukraini: Bibliografichnyi narys [Spiritual Mentors of the People: Kobzardom in Ukraine: A Bibliographical Essay]. Kyiv: Centralized library system of the Shevchenkivskyi district of Kyiv. (in Ukrainian)

3. Chaika S. V., Chaika M. M. (2012) Kobzarstvo - diievyi chynnyk zberezhennia tradytsii dukhovnoho zhyttia natsii [Kobzardom is an effective factor in preserving the traditions of the spiritual life of the nation]. Pedahohichna osvita: teoriia i praktyka [Teacher education: theory and practice], vol. 12, pp. 439-446.

4. Cheremskyi K. (1999) Povernennia tradytsii. $Z$ istorii nyshchennia kobzarstva [Return of traditions. From the History of the Destruction of Kobzardom]. Kharkiv: Les Kurbas Centre. (in Ukrainian)

5. Cherkaskyi L. M. (2003) Ukrainski narodni muzychni instrumenty [Ukrainian folk musical instruments]. Kyiv: Tekhnika. (in Ukrainian)

6. Cherneta T. O. (2009) Vydatni muzykanty Dnipropetrovshchyny. Lidiia Vorina [Outstanding Musicians of Dnipropetrovsk Region. Lidiia Vorina]. Dnipropetrovsk: Yurii Serdiuk. (in Ukrainian)

7. Davydov M. A. (2010) Istoriia vykonavstva na narodnykh instrumentakh (Ukrainska akademichna shkola) [History of Performance on Folk Instrument (Ukrainian Academic School)]. Lutsk: Volynska oblasna drukarnia. (in Ukrainian)

8. Dutchak V. G. (2010) Mykhailo Teliha: postat myttsia v konteksti epokhy [Mykhailo Teliga: The Figure of the Artist in the Context of the Era]. Naukovyi visnyk Natsionalnoi muzychnoi akademii Ukrainy imeni P. I. Chaikovskoho [Scientific herald of Tchaikovsky National music academy of Ukraine], vol. 91, pp. 249-261.

9. Hrynkiv R. D. (2010) Shliakhy udoskonalennia konstruktsii zvukoriadu bandury [Ways to improve the bandura scale design]. Chasopys Natsionalnoi muzychnoi akademii Ukrainy imeni 
P. I. Chaikovskoho [Journal of Tchaikovsky national music academy of Ukraine], vol. 1(6), pp. 61-67.

10. Ivannikova L. (2016) Khai M. Mykola Budnyk i kobzarstvo [Khai M. Mykola Budnyk and kobzardom] (Review) . Studii mystetstvoznavchi [Art History Studios], no. 1, pp. 110-113.

11. Khai M. (2007) Muzychno-instrumentalna kultura ukraintsiv (folklorna tradytsiia) [Musical-Instrumental Culture of Ukrainians (Folk Tradition)]. Kyiv; Drogobych: Kolo. (in Ukrainian)

12. Khotkevych H. (2002) Muzychni instrumenty ukrainskoho narodu [Musical instruments of the Ukrainian people] (Reprint 1930). Kharkiv: DVU. (in Ukrainian)

13. Kolessa F. (1969) Melodii ukrainskykh narodnykh dum [Melodies of Ukrainian Folk Dumas]. Kyiv: Naukova dumka. (in Ukrainian)

14. Panasiuk I. V. (2008) Tvorcha diyalinisti S. V. Bashtana $v$ kontecsti stanovlenya Kyivskoi shkoly akademichnogo bandurnogo vykonavstva [The Creative Activity S.V. Bashtan in the Context of the Establishment of the Kyiv School of Academic Bandura Performance] (PhD Thesis). Kyiv: Ukrainian National Tchaikovsky Academy of Music.

15.Panasiuk I. V. (2013) Kafedra bandury NMAU imeni P. I. Chaikovskoho ta peredumovy yii stvorennia [The Department of Bandura UNTAM Tschaikovsky and Prerequisites for its Creation]. Naukovyi visnyk Natsionalnoi muzychnoi akademii Ukrainy imeni P. I. Chaikovskoho [Scientific herald of Tchaikovsky National music academy of Ukraine], vol. 107, pp. 254-267.

16. Sliusarenko T. O. (2016) Bandurne vykonavstvo yak yavyshche natsionalnoi kultury [Bandura Performance as a Phenomenon of National Culture] (PhD Thesis). Kharkiv: I. P. Kotlyarevsky Kharkiv National University of Arts.

17. Suprun-Iaremko N. O. (2010) Muzykoznavchi pratsi [Musicological works]. Rivne: O. Zen. (in Ukrainian)

18. Trembitskiy A. M. (2007) Relighiyini motyvy ukrainskyh "nezryachih" mandryvnyh spivtsiv [Religious Motives of Ukrainian "Blind" Wandering Bards]. Narodna tvorchist ta etnohrafiia [Folk creativity and ethnography], no. 6, pp. 54-61.

19. Trembitskyi A. M. (2008) Arho nosiiv ukrainskoho "nezriachoho" epichnoho mandrivnoho mystetstva: stan naukovoi rozrobky problemy [The Cant of the Bards of the Ukrainian "Blind" Wandering Epic Art: State of Scientific Development of the Problem]. Ivan Ohiienko $i$ 
suchasna nauka ta osvita [Ivan Ohiienko and Modern Science and Education], vol. 5, pp. 110-148.

20. Vavryk O. (2006) Kobzarski shkoly v Ukraini [Kobzar Schools in Ukraine]. Ternopil: Zbruch. (in Ukrainian)

21. Yezhel Yu. (2017) Zrobysh banduru - vizmemo: Yak "posviachuiut" u suchasnykh kobzariv [You make the bandura - we will take you: how modern bandurists "are consecrated"]. Ukraina Moloda [Ukraine Young], 25 June, p. 13.

Information about the author:

Furdychko Andrii, orcid.org/0000-0002-2963-9794 Doctor of Arts, Associate Professor

Kyiv University of Culture 20, Chygoryna Str., Kyiv, 01601, Ukraine 